\title{
COMMUNITIES OF PRACTICE IN THE DESIGN OF A CURRICULUM FOR STUDENT TEACHERS OF ENGLISH
}

\author{
Liesel Hibbert, Cape Peninsula University of Technology \\ Hanlie Dippenaar, Cape Peninsula University of Technology
}

This article interprets the new Curriculum and Assessment Policy Statement for Further Education and Training for teacher education as an opportunity for creating communities of practice, which means viewing teaching and learning as socially situated (Barton, 1994: 68). A transliteracies framework for language development was used (Stornaiuolo, Smith and Phillips (2016: 4), which refers to resemiotisation. Guiterrez (2008) implies that, in an institutionalised learning context, it is acknowledged that multiple discourses come together around a specific task, such as in this case, English education. Multiple intersecting discourses are at play, and individuals develop meaningful connections to each other in the process of collaborative negotiation of meaning. In these communities, certain practices originate, and are developed, perpetuated and discarded, or adapted with the intention of expanding student linguistic and intellectual development. The content of the specific English teacher education curriculum design discussed here, is on globally pertinent issues of political, social and ecological ethics, in an attempt to address existing and persistent hierarchies of power while developing agency, voice, empathy and reflexivity, qualities which may enhance community development. A strong emphasis on critical reading, collaborative argumentation and engagement with text production is proposed, as a means of building community in the classroom.

Keywords: recurriculation, communities of practice, community development, English teacher education, transliteracies, resemiotisation

\section{INTRODUCTION AND BACKGROUND}

Due to the phasing in of the new Further Education and Training (FET) curriculum into teacher education in South Africa, the opportunity for innovation and renewal in the education of English teachers currently presents itself. This article suggests a 'communities of practice' theory base for English teacher education. The curriculum under discussion is based on the new Curriculum and Assessment Policy Statement (CAPS), and demonstrates how the CAPS guidelines can be interpreted in terms of underlying pedagogies. The focus of this programme is on building community within the classroom, for maximum uptake and transfer into schools. The idea is to address the persistent hierarchies of power between language groups, as well as reflexivity on the part of all participants. In addition, the aim is to develop graduate attributes, such as social responsibility, in terms of quality classroom management and community-building expertise in order to address existing reproductions of linguistic, ethnic, racial and religious barriers. Classrooms at teacher training level are still largely divided on racial, ethnic, religious, linguistic and class lines. While linguistic diversity is a reality and the global norm, the argument is that pre-service training of English language teachers lends itself to community development through reconstituting the classroom as an enquiry-based forum. This may be achieved through critical deliberation and ongoing 
structured argumentation with the aim of building a community of practice within the group, as well as between the facilitator and the students.

The vision we have for teacher education implies that the general purpose of the current BEd programme is to prepare teachers to become self-reflective community-building practitioners and facilitators. This requires students to understand what it entails to expand the capacity to critically reflect on their own choices of action in the classroom. Any course or module needs to adhere to the general graduate attributes and competencies which form part of a comprehensive teacher development programme. Pre-service teachers need to display, to both learners and evaluators, their personal motivation, and to visibly model commitment to social responsibility and inclusion. These attributes are developed within the framework of the expected seven roles of the teacher as prescribed by the Norms and Standards for Teachers in South Africa (Department of Basic Education (DBE), 2000: 12). The principles underlying the policy are the following (DBE, 2000: 12):

a teacher is required to be a specialist in a particular learning area, subject or phase, a specialist in teaching and learning, a specialist in assessment, a curriculum developer, a leader, administrator and manager, a scholar and lifelong learner, and a professional who plays a community, citizenship, and pastoral role.

The language teaching approaches suggested were drawn from the CAPS document, which states the required language teaching approach as involving a text-based, communicativebased and historically-based positioning of texts (DBE, 2011: 9). Student teachers should be prepared not only to teach the CAPS but also to build future communities with enquiry-based dispositions. Teaching of vocabulary, grammar, discourse and genre are required to be taught in context. Language development is seen as being for personal as well as professional empowerment (based on an individually-motivated and research-driven process approach).

The pre-service teacher also needs to demonstrate a high level of critical reading and writing and metacognition. The CAPS requirements for English Home Language Grades 7 to 9 (DBE, 2011: 9) specify four areas of concentration, each of which should be part of the suggested language competency units per year, namely, listening and viewing (critical comprehension), reading and viewing (literature), and writing and presenting. We strongly suggest that all genres specified by the CAPS language curriculum should appear in each thematic unit, i.e., factual discipline-related texts, short stories, poetry, novels, drama, film, popular literature and media (e.g., journalism, news, online and print). Alongside this, grammar, register, critical language awareness, critical discourse analysis, and historical and current aspects of English as a local and global language are addressed. Furthermore, we aim - as far as possible, given the contextual constraints - to produce graduates who have critical views on global trends and key issues (e.g., migration, urbanisation, environmental and human rights renewals and ethics), in other words, a general knowledge approach, as well as creative engagement in terms of independent text production. In order to address student language development, and social, class and linguistic hierarchies, a transliteracies framework is suggested, which is theme-based, literature-based and discourse-based.

\section{A TRANSLITERACIES FRAMEWORK}

The term 'cultural diversity' is preferred to the term 'multiculturalism', and 'linguistic diversity' to the term 'multilingualism'. The term 'linguistic diversity' is preferred as it signals infinite discourse-based complexities, hierarchies of power and ways of speaking, rather than the use of a number of languages alongside each other. For the sake of 
convenience, in the postcolonial era, the phenomenon of unregulated and regulated text that Sebba (2012: 5) views as a continuum, rather than completely separated, has been glossed over. The drive for English only, on the part of the academy, is still prevalent. For instance, people of colour are referred to by the academy in South Africa generally as 'diverse', despite the fact that everyone is 'diverse' in a multitude of ways and configurations of culture (Bangeni \& Kapp, 2008: 255). The label 'diverse students', as opposed to 'white' students, used within the academies indicates that students in South Africa are still largely perceived as two or three historically-based distinct groups by academics, as was customary in the apartheid-era education system. In order to move away from such institutionally entrenched perspectives, misconceptions and distorted categorisation, certain key pedagogies are discussed with direct reference to the conceptualised English curriculum, with the aim of rendering the curriculum inclusive.

\section{COMMUNITIES OF PRACTICE}

The lens used to view teaching and learning is that of 'communities of practice', in which language is viewed as socially situated (Barton, 1994: 68). This is described in more detail in terms of the multi-literacies framework for language development (Cope \& Kalantzis, 2000: 5). The framework views any communicative situation in an institutionalised learning context as a coming together of multiple discourses around a specific task. According to the framework, learning communities are communities in which certain practices originate, and are developed, perpetuated and discarded, or adapted with the intention of moving them forward. This raises the question of what definitions there might be of 'moving forward'. To some educationists and education policymakers this kind of progression would mean education for mere economic gain. From a more comprehensive, inclusive and human rights perspective, performance and 'progress' in complex literacy performance are ideally measured by a cluster of variables. These variables do not exclude economic wellbeing but do include such variables as social wellbeing, and what Winberg, Ntloko and Ncubukezi (2015: 5) refer to, as many others do, as a strong senses of agency and voice. This implies that the aim of language education for enhanced equity in South Africa would be that of meaningful connections of individuals to each other in loosely formed communities. Within the classroom, these communities are ideally created with a life-long aim of carry-over into community-building in civil society and schools.

We view academic staff and students as practitioners, having no artificial dichotomy between them and no entrenched autocratic relationships, but instead as being engaged in dialectic interaction (Engeström \& Sannino, 2011: 371) between participants and facilitators/mentors in the learning process. In this community, a student moves from being an apprentice to being a practitioner, in the process acquiring and being able to confidently and competently negotiate within a number of multiple shifting discourses. In order to achieve this kind of egalitarian ethos, some groundwork is required by the faculty and staff. Students continue to have expectations of top-down relationships with facilitators, expectations which may in turn continue to undermine their agency or their sense of responsibility towards their own education and themselves, while also impacting negatively on their personal development and performance. Therefore, Sale's (2015: vii) core principles of learning are applied, especially with regard to the promotion of active and experiential learning, with a focus on self-directed learning and a simultaneous facilitation of the development of critical thinking.

The curriculum suggested is based on a triangular model of activity (Engeström, 1999: 34) and is applied to develop the 'critical consciousness' of student teachers through a 
combination of activities and tools. Bearing in mind the arguments of Engeström and Sannino (2011: 371), student teachers should be agents in their own academic and professional development within the community of the university context. Students and lecturers participate in a complex activity system of actions, tools, members, rules and 'a community' (Engeström, 1991: 136). According to this model, the lecture hall becomes the site for interventions (rules) and praxis that extend beyond theory and create opportunities for the formation of communities of practice, as described by McMillan (2009: 11). For this purpose, boundary zones (McMillan, 2009: 11) within which classroom discussions take place are reconstituted.

Learning, within the activity theory framework as interpreted by Dippenaar, Liebenberg and Bosman (2016: 180), is a collective process leading to the activity of creating change. These concepts relating to activity theory are now briefly described in terms of the activity system framework informing the English curriculum as we have conceptualised it, specifically the three components: subjects, objective and community. The subjects in the activity system are students who are studying to be English teachers in the FET phase (Grades 7-12). The primary objective or motive of this activity system is to enhance the content knowledge of the students in English as part of their preparation to be English teachers. This is a reciprocal objective or goal, as the student teachers are practising and developing their individual content knowledge as well as their communication and pedagogical skills, both of which form part of their professional development as English teachers. According to our curriculum as it is conceptualised, this happens when they are given authentic opportunities to develop and practise these skills.

The community in this activity system is the Department of English, which consists of English lecturers and students of English who will be teaching in the senior and FET phases. They form part of the larger activity system of the institution and the national and provincial Department of Education. The relationship of the community to the elements within the activity system is realised via rules and the division of labour. The primary division-of-labour classification is based on the English students' interactions with their respective lecturers and peers. However, secondary to that are the organisational, collaborative and facilitated activities offered by the lecturer to the students. The mediating tools and artefacts are the students' portfolios, which may include all of their written tasks, their own notes and reflections, and feedback. These tools also include any resources used by the students. The rules in the activity system include those to do with the organisation, objectives, assessment criteria, and norms and values, all of which were shared, or perhaps negotiated, with the students before the onset of the first lectures.

Jaworski and Goodchild (2006: 359) argue that the value of activity theory is the 'possibility of exploring the mediating elements and the dialectical relationships' between all the elements within the activity system (tools, subject, object, outcome, rules, community and division of labour). This is done by creating a context in which our English student teachers experience learning in terms of learning something new, a process which requires reconceptualisation and critical reflection (Goodyear \& Zenios, 2007: 355). They do this by interacting as professional learning communities. These professional learning communities create opportunities to engage with content in relation to their own learning and to improve their practice as teachers (Vescio, Ross \& Adams, 2008: 160). This development of learning communities as part of teacher education is an emerging form of teaching preparation (Daniel, Auhl \& Hastings, 2013: 160; Le Cornu \& Ewing, 2008: 1880). 
In terms of collaborative and critical reflection, Daniel et al. (2013: 160) found that future teachers who participate in professional learning communities develop an awareness of the role of a teacher in their own professional development. During this process, critical reflective thinking starts as a mediating tool, through the use of specific activities to facilitate inquiry (Goodchild, Fugelstad \& Jaworksi, 2013: 4). The Department of Higher Education and Training's Integrated Strategic Planning Framework for Teacher Education and Development in South Africa (2011) also recommends the formation of professional learning communities.

\section{RECURRICULATION FOR FET ENGLISH TEACHER EDUCATION IN SOUTH AFRICA}

\section{Prerequisites for successful implementation}

The success rate of the curriculum implementation will depend on the institutional, student and collegial buy-in of the participants regarding division of roles and responsibilities. Collegial buy-in implies no fear of change, no attachment to past habits, and being keen on changing the environment and sharing power with students. With reference to institutional buy-in, metaphorically speaking, one cannot play tennis on a hockey field, even with the best players or intentions. The field needs to be shaped and laid out in order to facilitate the desired outcomes. In other words, the context, the faculty, the institutional arrangements and in-house university ethos and provisions available, and the impact of the conceptualised curriculum on the quality of teaching and learning all need to be considered. What these variables are, how they may need to be modified to impact positively, as well as, depending on a large number of variables, whether and how they vary from institution to institution, also need to be identified, considered and addressed timeously and upfront, i.e., before the beginning of the academic year. There may be instant support from staff in terms of their being open to innovation. On the other hand, staff may struggle with the idea of change or with a fear of being overburdened with 'extra work'. Staff may fear the creation of a zone of 'discomfort' together with the knee-jerk reactions that erupt during negotiation of differences of opinions and the search for consensus. It has been established that the attitude of the lecturer to students and to his/her profession is a main variable in the quality of educational outcomes, especially where attitudes to diversity in a student body are concerned (Bongeni \& Kapp, 2008: 256). In terms of student buy-in, it is required that they are in possession of the material and books needed. They need to be motivated, committed, curious, self-driven, connected to current affairs, organised, mature, and wanting to commit and contribute as far as possible to the idea of the establishment of a successful, optimally-functioning learning community.

In terms of adequate resources to support the conceptualised curriculum, one of the variables listed above which needs to be addressed upfront and in advance of the next year, is the availability and development of materials so that suitable or existing textbooks and other resources, together with matching pedagogies, are agreed upon by lecturers and are in place when students arrive.

Finally, a curriculum or programme such as the one described here requires a certain way of looking at, a certain perspective or lens, and a certain way of talking about the situation, time, space and place. Producing a common discourse or way of talking about teaching and learning (i.e., a meta-language of teaching and learning) which facilitates and ensures staff and student wellbeing as well as a sense of achievement and empowerment, together with 
real evidence of academic progress, are measures of success. Three qualities prescribed by CAPS are for the curriculum to be theme-based, text-based and geared for critical analysis.

\section{Themes}

The themes suggested below were selected on the basis of socially responsible ethics (as mentioned in the underpinnings of CAPS), and for the purposes of defamiliarisation, which is broadly defined as the artistic technique of presenting common things to audiences in an unfamiliar or strange way, in order to enhance perceptions of the familiar. These themes, or a selection thereof, can be dealt with individually or grouped together under broad overarching themes, as demonstrated further along, the preparation for which could be a collaborative project for lecturers or lecturers together with their students.

For the purposes of this article, defamiliarisation is applied by engaging students in the study of, for instance, an African text with a key social issue addressed, in tandem with a text from another country or context which deals with a similar issue. It needs to be emphasised that texts from different parts of Africa may be just as unfamiliar to students as literature from their own country, in this case, South Africa. The principle of defamiliarisation is thus not just simplistically African versus 'other', but the creation of intersectional conversations about class, culture, gender and race across the globe.

Suggested themes for the year (subscribing to the agenda of social responsiveness and democratic community building) could be: cities in transition, youth and emerging adulthood, identities in transition, my language history, translanguaging, generation gaps, youth discourses in unregulated spaces versus mediated discourses in regulated spaces such as academe, food and family, prejudice, greed, power and poverty, migration, love and war, 'What makes a real hero/heroine?', families in Africa, parenthood, environment and waste, peer network and friendship circles, and gender dynamics. The language teaching approaches suggested were drawn from the CAPS document, where it states the required language teaching approach as involving a text-based, communicative-based and historically-based positioning of texts (DBE, 2011: 9).

We suggest that students should have three assessment and feedback opportunities per 10week cycle. This would consist of an oral (10\%), a short piece of writing (10\%) and a long essay (10\% in the first two cycles). This means that students whose writing competencies are weak, but who are strong in oral presentation, can still experience success, based on a strong oral mark. In the third cycle, the long research essay will count $20 \%$, which is more than the other two components. The weaknesses in academic writing are therefore catered for in the assessments and are addressed incrementally, by more weighting at the end of the year than at the beginning of the year. The next section outlines variables which may impact on the desired success rate of the implementation.

Table 1 below serves as a sample of a planning document in the form of a grid. The grid gives an easy overview of the four years of training, in terms of content organised under certain themes. The theme approach allows for creativity within the framework, as well as choices regarding the topics learners would like to follow up on. The resultant curriculum framework document for collaborative discussion would thus be planned according to the diagram shown in Table 1. 
Table 1: Example of a planning document

\begin{tabular}{|l|l|l|l|}
\hline Year of study & SAQA level & Themes & $\begin{array}{l}\text { Examples of } \\
\text { suggested/possible student } \\
\text { tasks }\end{array}$ \\
\hline English Studies 1 & 5 & $\begin{array}{l}\text { Choose 3 themes for } \\
\text { the year }\end{array}$ & $\begin{array}{l}\text { Annotated bibliographies, } \\
\text { discussions, action research } \\
\text { projects, portfolio development }\end{array}$ \\
\hline English Studies 2 & 6 & $\begin{array}{l}\text { Choose 3 themes for } \\
\text { the year }\end{array}$ & $\begin{array}{l}\text { Community engagement } \\
\text { initiatives, discussions, } \\
\text { workshops, continued portfolio } \\
\text { development }\end{array}$ \\
\hline English Studies 3 & 6 & $\begin{array}{l}\text { Choose 3 themes for } \\
\text { the year }\end{array}$ & $\begin{array}{l}\text { In depth analysis of literature, } \\
\text { critical analysis, presentations, } \\
\text { continued portfolio } \\
\text { development }\end{array}$ \\
\hline $\begin{array}{l}\text { English Studies 4 } \\
\text { (Methodology) }\end{array}$ & 7 & $\begin{array}{l}\text { Theory and practice } \\
\text { of English Studies, } \\
\text { i.e., language } \\
\text { acquisition and } \\
\text { literacy development }\end{array}$ & $\begin{array}{l}\text { Materials development, in- } \\
\text { school research, surveys of } \\
\text { successful methodologies and } \\
\text { influential theories, seminars, } \\
\text { final presentation of portfolios }\end{array}$ \\
\hline
\end{tabular}

The Grade 7-8 school curriculum will be dealt with in the first year of the English Methodology course, the Grade 9 curriculum will be dealt with in second year, the Grade 1011 curriculum in the third year, and the Grade 12 curriculum in the fourth year. Simultaneously, everything stipulated in the CAPS English as a Major teaching subject will be translated into 'how to teach it', following CAPS requirements, in the English Methodology class, which means that content and methodology are integrated as far as is possible. Although methodology is officially separated under a separate code at present, we are treating the content and methodology as integrated, in that the methodological activities and lesson planning done by the students for their practice teaching are based on the content presented by the lecturers.

Anticipatory guides as suggested by Walqui (2006: 159) are implemented, which means that, at the beginning of a new topic, the teacher may ask his/her class to collaborate in filling out a two-column anticipatory guide, with one column for what students know about a topic and the other for questions about the topic that they are interested in answering. The following pattern would be followed each week: in the first contact session, the lecturer raises a proposition regarding an issue at hand (theme-related). In the second session, the students analyse and prepare a written response to a reading provided in the initial discussion period. In the third session, the lecturer provides further input, provides clarifications and answers questions. The fourth session could be a tutorial task, based on the week's activities. This would normally be a refined response to one or two readings. In order to facilitate integration of language and literature, each theme is then developed to include tasks, genres and activities specified by the CAPS documentation. 


\section{Texts}

What follows is a list of recently published African/South African writers, some being young, first-time authors. Future English teachers need to be on the forefront of current books available for children or young adults and need to acquire the skill to select books appropriate for their learners. This is done through building criteria for book selection into the pre-service English teacher education curriculum.

It is important to consider student interest when choosing themes and texts, which requires dialogue and collaboration between lecturers and students and which might vary between campuses and contexts. As pointed out by Freire (2005), without dialogue, there is no communication, and without communication, no education. Freire (2005: 77) points out that dialogue exists in a 'horizontal relationship of mutual trust'; if there is no dialogue, education becomes merely a 'banking method'.

Examples of current texts that may be considered, include Because Pulu means Rain by Jenny Robson, Sweet Medicing by Panache Chigumadzi (gender inequality and patriarchy theme), We Need New Names by No Violet Bulawayo, Glowfly Dance by Jade Gibson (migration), Bom Boy by Yewande Omotoso, Reef by Gunesekera Romesch, Rachel's Blue by Zakes Mda, October by Zoe Wicomb, The Yearning by Mohale Mashingo (folklore), The Eighth Man by Michal Williams (youth literature), The Reactive by Masanda Ntsganga, Under the Udala Trees by Chinelo Okparanta, Affluenza by Niq Mhlongo, Rumours by Mongane Wally Serote, Woman Next Door by Yawande Omotoso, Bricklane by Monica Ali, Purple Hibiscus and Americanah (migration theme) by Chimamanda Ngozi Adichie, Joys of Motherhood by Buchi Emecheta (motherhood in Africa), and Nervous Conditions by Tsitsi Dangarembga (youth and identities in transition).

Newly published short stories may include Love Interrupted by Reneilwe Malatji, Tjieng Tjang Ttjerries by Jolyn Phillips (written in Cape dialect), Stations by Nick Mulgrew or Writing What We Like edited by Yolisa Qunta. These texts can either be used because students relate easily to the context or to specifically defamiliarise the text by studying it alongside literature from other continents where similar issues are explored. Suggested newly published African poetry collections include Matric Rage Genna Gardini and Water by Koleka Putuma. As way of disclaimer, we would like to emphasise that, because students are located in Africa, African literature is equally familiar/unfamiliar to them, due to the diversity of culture and languages, as well as starkly contrasting experiences which people often have of 'Africa' or South Africa. It is clearly understood that students enjoy elements of the traditional English canon, but these also need to be presented as part of practices in intersectionality.

Films that have been successfully included at pre-service teacher education level so far are Tsotsi, The Freedom Writer's Diaries, and The Story of Ron Clark. These films can be combined with items from CAPS requiring knowledge of and/or competency in reading and viewing, as well as creating, posters, charts, maps, graphs, cartoons, magazines, newspapers, websites, documentaries and TV series (Department of Basic Education, 2011: 34).

In summary, critical reading and writing, vocabulary-building, understanding global trends and key issues (e.g., migration, urbanisation, environmental and human rights renewals and ethics), in other words, a general knowledge approach, together with a creative engagement such as text production (creative writing) are essential activities to be linked to the study of literature. 
In 2017, the teaching year consisted of roughly three cycles: eight weeks in the first cycle, six weeks in the second and another eight weeks in the third. Some additional weeks of the academic year are allocated to teaching practice in schools. In the first year, English Studies will be dealt with on SAQA level 5. In the second and third year, it will be dealt with on SAQA level 6, as prescribed. The second- and third-year curriculum will consist of increasingly independent web-based research and group collaboration between students, with increasing demands made on them for text production and consumption. The materials will be presented as a menu system with five or six thematic choices, of which four are compulsory, one theme per term over four terms. Themes are to be chosen by lecturers in collaboration with students at the end of the year for the coming year, so that materials are ready at the onset of term, and should ideally be negotiated with students. It is suggested that each year deal with three overriding themes.

\section{Critical discourse analysis}

In summary, critical reading and writing, vocabulary-building, understanding global trends and key issues (e.g., migration, urbanisation, environmental and human rights renewals and ethics and literacy development), in other words, a general knowledge approach, together with a creative engagement such as text production (creative writing), are essential activities to be linked to the study of literature.

Texts will be chosen from a variety of genres with prescribed activities linked to the above: short stories, visuals, drama, novel, poetry, film, and online and print media. Students will be introduced to the socio-political and cultural context of South Africa, but will also be defamiliarised by comparing the South African context to similar and/or contrasting contexts elsewhere in the world (e.g., Eurocentric or American), all within the specific theme.

Grammar, vocabulary (related to the theme), discourse features (art, public documents, forms, letters, and online and print media), and historical and current features English as a global and local language, are to be covered as part of the Grade 10 curriculum from the third year onwards. Prior to that, it is assumed that students will have developed their own language proficiency as an integrated part of the course.

Grammar will be integrated with the theme and texts of the specific 10-week cycle. Items will include nouns, noun types, verbs, pronouns, pronoun types, adverbs, tenses, clauses, phrases and sentences, adjectives, negations, conjunctions, ideophones, interjections, interrogatives, direct and indirect speech and voice (passive and active) - related as far as possible to writing style and the selected texts.

Vocabulary items (as listed in the CAPS documentation) should be linked to the study of literary and/or varied prescribed texts. They are: spelling patterns and rules, complex and new vocabulary, compiling of a new list, borrowed and inherited words, neologisms, honorifics, abbreviations, acronyms, thesaurus vs dictionary, leadwords and spelling, pronunciation, etymology, prefixes, suffixes, paronyms and polysemes, homonyms, antonyms, homophones, puns and malapropisms (as listed in the CAPS documentation). Discourse features and discourse analysis will include idiomatic expressions, idioms, proverbs, figurative language and critical language awareness, which could be linked to set works. In addition, historical aspects of English as a local and global language will be addressed, as they are closely related to the Grade 12 curriculum.

An initial detailed mind-map of a theme-based curriculum may look as follows: 


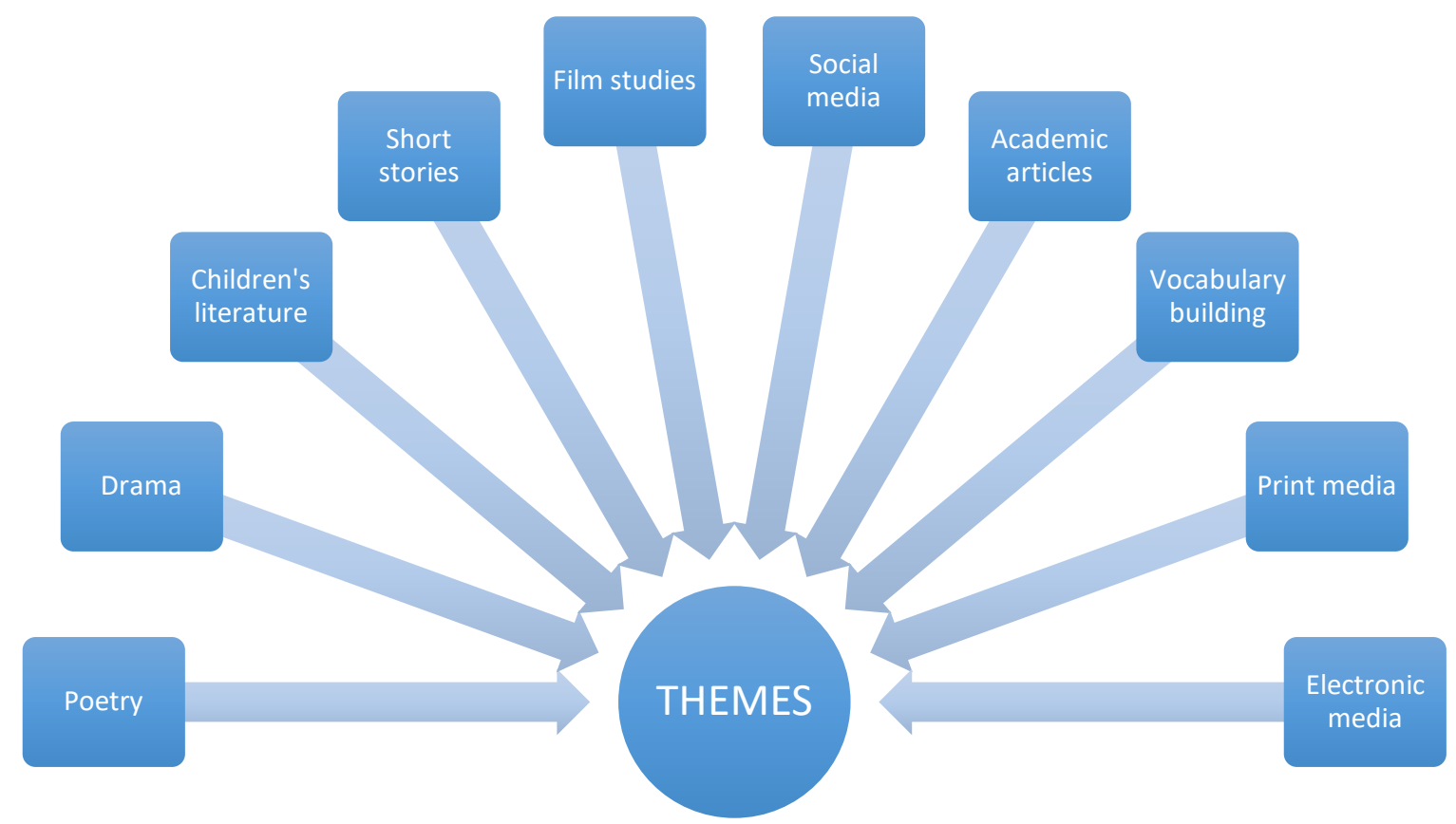

Figure 1: Possible genres to include in a theme-based curriculum

An example of planning the curriculum is as follows:

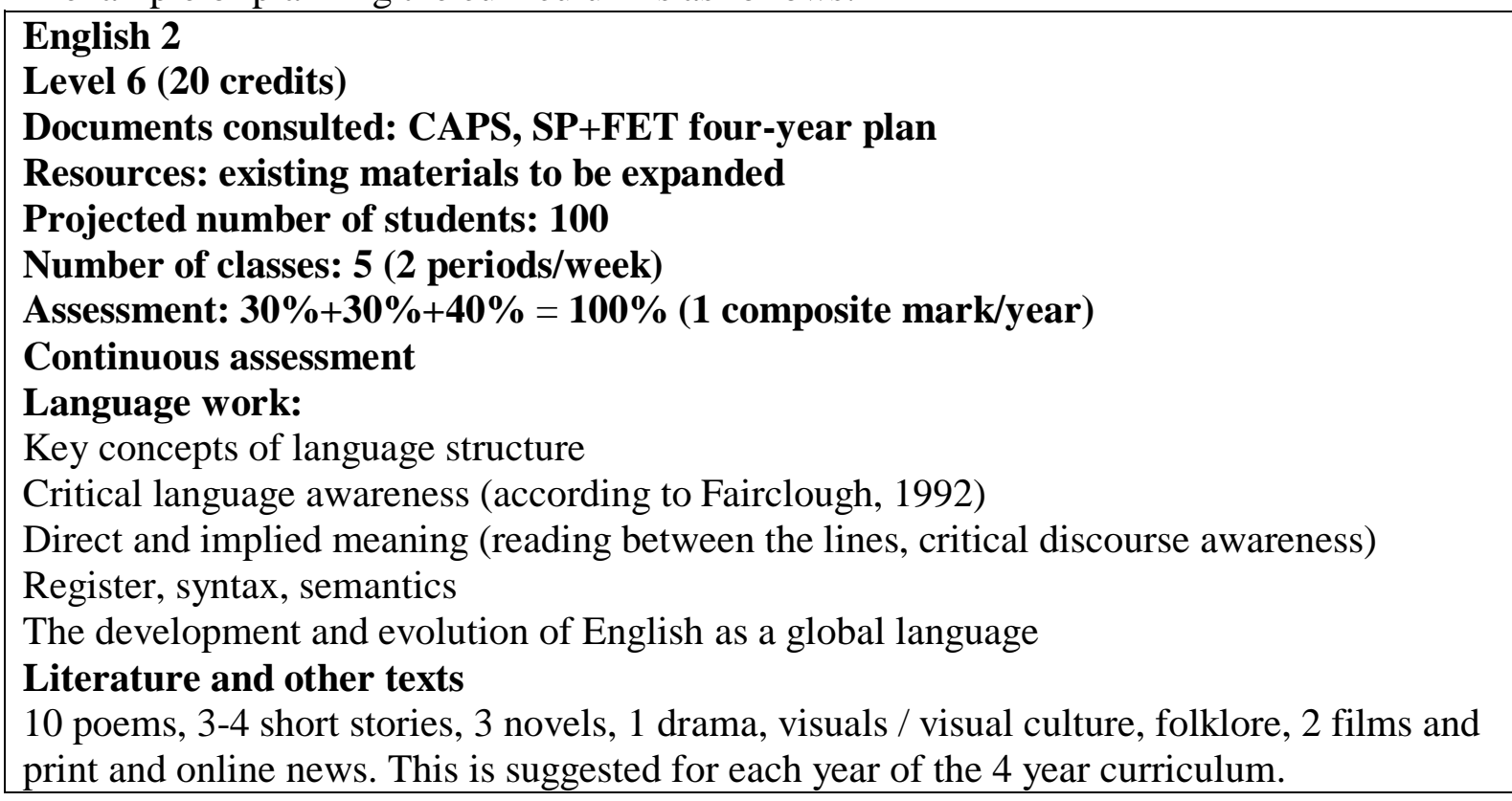

\section{CONCLUDING OBSERVATIONS}

Some pilot work in collaborative engagement and community-building conducted in 2016 with first-year English Studies students in two classes of 70 each has elicited overwhelmingly positive responses from students, such as:

We got the chance to form our own opinions and to express them as well.

We are moving and stepping out of our comfort zones in terms of participation in class. 
We are forced to develop our own thinking.

This interactive learning method is very beneficial.

We learnt how to work through a poem independently.

My mind was refreshed and I have been impacted.

I would suggest that the active learning method should be used often for further courses as it really helps for one to understand the work much better.

Research coming out of such processes as described above should address the question of what constitutes quality professional literacy development. It is suggested that ongoing collaboration between teaching staff as well as with students, more equitable access to, as well as appropriate and satisfactory training of, lecturers in technology, and the creation of peer learning communities be key elements of teacher pre-service education, lifting the process of teacher education out of pervasive and persistent traditional, outdated chalk-andtalk rote-learning norms. Curriculum development is an ongoing, dialectic process which needs reflection and participation from all stakeholders.

When literacy development tasks in English are directly geared to participants' 'beings' and 'doings' (Loots \& Walker 2016: 266), in other words, linked to those activities which are pertinent to the students' own life aims and projected future identities, students seem to respond positively. Authentic resources and a task-based curriculum, incorporating peer group and e-learning, enable students to grow intellectually and socially, and to develop a strong sense of awareness of self and others. This brings us back to the two main theoretical constructs which frame the argument, namely, transliteracies and communities of practice. Transliteracies refer to active text production as well as recognition of global Englishes, while valuing own variations and dialects. This is built into the cross-cultural nature of the material and the creative and critical activities students are exposed to. Communities of practice include staff collaborations not only with colleagues, but also with students. Classroom organisation, which is based on an interactive model, is the key to creating communities of learning which facilitate critical literacy. One of the students who has been exposed to this pedagogy in a recent study (see reference to Hibbert \& Waghid), responded by saying: 'You are actually doing your own work.' When asked to explain this statement a bit further, the student indicated that a marked shift in perception of what teaching means, had occurred for him. He had mainly seen the teachers and lecturers doing all the work in class. He now realised that each student, through being part of a transliterate learning community, can, and ought to, be prompted to engage and to produce their own ideas, opinions, artefact, and that contributions to the group or class discussion are reliant on student engagement.

\section{REFERENCES}

BARTON, D. 1994. Literacy - an introduction to the ecology of written language. Oxford: Blackwell.

BANGENI, B \& R KAPP. 2008. Shifting language attitudes in linguistically diverse learning environment in South Africa. Journal of Multilingual and Multicultural Development, 28(4):253-269.

COPE, B \& M KALANTZIS (Eds). 2000. Multiliteracies: literacy learning and the design of social futures. New York: Routledge. 
DANIEL, GR, G AUHL, \& W HASTINGS. 2013. Collaborative feedback and reflection for professional growth: preparing first-year pre-service teachers for participation in the community of practice. Asia-Pacific Journal of Teacher Education, 41(2):159-172.

DEPARTMENT OF BASIC EDUCATION. 2000. Norms and standards for educators. Government Gazette, 418(20844):1-33.

DEPARTMENT OF BASIC EDUCATION. 2011. National Curriculum Statement, Curriculum and Assessment Policy Statement Grades 7-9 English Home Language. Pretoria: Government Printers.

DEPARTMENT OF HIGHER EDUCATION AND TRAINING. 2011. Integrated strategic planning framework for teacher education and development in South Africa 20112025. Pretoria: Government Printers.

DIPPENAAR, H, R LIEBENBERG, \& V BOSMAN, 2016. Service-learning and preservice teachers from a university of technology in South Africa: multiple mediations of change. In Winterbottom, C \& VE Lake (Eds), Praxeological learning: servicelearning in teacher education. New York. Nova Science Publishers. 179-207.

ENGESTRÖM, Y. 1991. Activity theory and individual and social transformation. Multidisciplinary Newsletter for Activity Theory, (7/8):14-15.

ENGESTRÖM, Y. 1999. Activity theory and individual and social transformation. In Engeström, Y, R Miettinen \& R-L Punamäki (Eds), Perspectives on Activity Theory. Cambridge: Cambridge University Press. 19-39.

ENGESTRÖM, Y \& A SANNINO. 2011. Discursive manifestations of contradictions in organizational change efforts. Journal of Organizational Change Management, 24(3):368-387.

FREIRE, P. 2005. Pedagogy of the oppressed (30th anniversary ed). New York: Continuum.

GOODCHILD, S, A FUGELSTAD \& B JAWORSKI, 2013. Critical alignment in inquirybased practice in developing mathematics teaching. Educational Studies in Mathematics, 84(3):393-412.

GOODYEAR, P, \& M ZENIOS, 2007. Discussion, collaborative knowledge work and epistemic fluency. British Journal of Educational Studies, 5(55):351-368.

GUITERREZ, KD. 2008. Developing sociocritical literacy in the Third Space. Reading Research Quarterly, 43(2):148-164.

HIBBERT, L \& Z WAGHID. 2017. Decolonising pre-service teachers' colonialist thoughts in higher education through defamiliarisation as a pedagogy. Educational Research for Social Change, forthcoming.

JAWORKSI, B \& S GOODCHILD. 2006. Inquiry community in an activity theory frame. In J. Navotná, H. Moraová, M. Krátká \& N. Stehliková (Eds.). Proceedings of the 30th Conference of the International Group for the Psychology of Mathematics Education. 3:353-360. Prague Czech Republic: Charles University in Prague.

LE CORNU, R \& R EWING. 2008. Reconceptualising professional experiences in preService teacher education ... reconstructing the past to embrace the future. Teaching and Teacher Education, 24(7):1799-1812.

LOOTS, S \& M WALKER. 2016. A capabilities-based gender equality policy for higher education: conceptual and methodological considerations. Journal of Human Development and Capabilities, 17(2):260-277.

MCMILLAN, J. 2009. Through an activity theory lens: conceptualizing service learning as 'boundary work'. International Journal of Community Research and Engagement, 2(0):39-60.

SALE, D. 2015. Creative teaching: an evidence-based approach. Singapore: Springer. 
SEBBA, M. 2012. Orthography as socoal action: scropts, spelling, identity and power. (in) Jaffe, A, J Androutsopoulos, M Sebba \& S Johnson (Eds), Orthography as social action: scripts, spelling, identity and power. Berlin: De Gruyter.

SOUTH AFRICA. 2015. National Qualifications Framework Act (67/2008): revised policy on the minimum requirements for teacher education qualifications. Government Gazette, 38487(596).

STORNNAIUOLO, A, A SMITH \& N PHILLIPS. 2016. Theorizing a transliteracies framework for a connected world. Journal of Literacy Research, 49(1):1-24.

VESCIO, V, D ROSS, \& A ADAMS. 2008. A review of research on the impact of professional learning communities on teaching practice and student learning. Teaching and Teacher Education, 24:80-91.

VOSS, R, T GRUBER \& I SZMIGIN. 2007. Service quality in higher education: the role of student expectations. Journal of Business Research, 60(2007):949-959.

WALQUI, A. 2006. Scaffolding instruction for English language learners: a conceptual framework. The International Journal of Bilingual Education and Bilingualism, 9(2):159-180.

WINBERG, C, N NTLOKO, \& T NCUBUKEZI. 2015. 'Don't leave before you understand': supporting masters candidates in Business Studies. Christal, 3(1):1-20.

\section{BIOGRAPHICAL NOTES}

Hanlie Dippenaar is a senior lecturer in the Faculty of Education, CPUT, Wellington, where she lectures English and Curriculum studies. She holds a PhD from the Northwest University and her research interests are in Community Engagement, Academic Service-learning, Language teaching, Computer-assisted Language Support and Academic Writing in Higher Education.

Liesel Hibbert is Associate Professor in English Education at the Cape Peninsula University of Technology. She received her Ph.D. in Linguistics from the University of Cape Town. Her research spans global trends in youth development and multilingualism, academic and language development in higher education, linguistic ethnography, and South African writing, including children's literature. 